\title{
Chapter 16 \\ Bridging Conventional and Molecular Genetics of Sorghum Insect Resistance
}

\author{
Yinghua Huang, Hari C. Sharma, and Mukesh K. Dhillon
}

\begin{abstract}
Sustainable production of sorghum, Sorghum bicolor (L.) Moench, depends on effective control of insect pests as they continue to compete with humans for the sorghum crop. Insect pests are a major constraint in sorghum production, and nearly 150 insect species are serious pests of this crop worldwide and cause more than $9 \%$ loss annually. Annual losses due to insect pests in sorghum have been estimated to be $\$ 1,089$ million in the semiarid tropics (ICRISAT Annual report 1991. International Crop Research Institute for Semi-arid Tropics. Patancheru, Andhra Pradesh, India, 1992), but differing in magnitude on a regional basis. Key insect pests in the USA include the greenbug, Schizaphis graminum (Rondani); sorghum midge, Stenodiplosis sorghicola (Coquillett); and various caterpillars in the Southern areas. For example, damage by greenbug to sorghum is estimated to cost US producers $\$ 248$ million annually. The major insect pests of sorghum on a global basis are the greenbug, sorghum midge, sorghum shoot fly (Atherigona soccata Rond.), stem borers (Chilo partellus Swin. and Busseola fusca Fuller), and armyworms (Mythimna separata Walk and Spodoptera frugiperda J.E. Smith). Recent advances
\end{abstract}

Mention of a trademark or proprietary product does not constitute a guarantee or warranty of a product by the US Department of Agriculture and does not imply its approval to the exclusion of other products that may also be suitable.

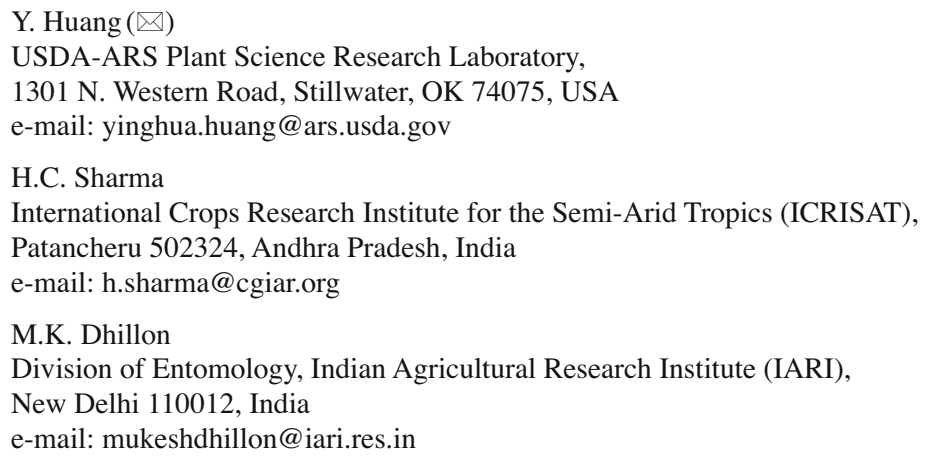


in sorghum genetics, genomics, and breeding have led to development of some cutting-edge molecular technologies that are complementary to genetic improvement of this crop for insect pest management. Genome sequencing and genome mapping have accelerated the pace of gene discovery in sorghum. Other genomic technologies, such as QTL (quantitative trait loci) mapping, gene expression profiling, functional genomics, and gene transfer are powerful tools for efficient identification of novel insect-resistance genes, and characterization of the key pathways that regulate the interactions between crop plants and insect pests leading to successful expression of the host plant defense. Traditional breeding methods, such as germplasm evaluation and enhancement, backcrossing, pedigree selection, and recurrent selection continue to play important roles in developing insect-resistant cultivars with major resistance genes; and new cultivars with enhanced resistance to several important insect pests are released continuously. Future research efforts should focus on identification of new sources of resistance, characterization of resistance genes, and dissecting the network of resistance gene regulation. Collaboration between research institutions and the sorghum industry as well as international cooperation in utilization of emerging knowledge and technologies will enhance the global efforts in insect pest management in sorghum.

\section{Introduction}

Sorghum [Sorghum bicolor (L.) Moench] is grown in warm and humid environments that often favor the proliferation of many insect pests. In addition, long growth periods of some varieties such as sweet sorghum and forage sorghum, cultivation of genetically homogeneous hybrids/varieties on large acreages, and the practice of multicropping sorghum and rotation by intercropping with common host plants throughout the years result in the buildup of pest populations. Thus, insect pest populations often exceed the economic-injury level in most of the sorghum-growing areas.

\section{Insect Pests of Sorghum}

Numerous insects attack sorghum worldwide. More than 150 insect species are considered pests of sorghum (Sharma 1993), and about 20 of them can cause severe economic damage to the crop. A summary of the major insect pests of sorghum is listed in Table 16.1 and described in detail, including their geographical distribution, biology, feeding characteristics, and symptoms of damage. Like most field crops, sorghum is usually attacked by only a few key pests in each agro-ecosystem (Young and Teetes 1977). Primary insect species on sorghum vary depending upon the location and the environments. Depending on sorghum agro-ecosystems, one or a few key insect pests, such as greenbug, Schizaphis graminum (Rondani), sorghum 
Table 16.1 Major insect pests of sorghum

\begin{tabular}{|c|c|c|c|}
\hline Common name & Scientific name & $\begin{array}{l}\text { Geographical } \\
\text { distribution }\end{array}$ & $\begin{array}{l}\text { Feeding characteristics } \\
\text { and damage }\end{array}$ \\
\hline $\begin{array}{l}\text { African (Nutgrass) } \\
\text { Armyworm }\end{array}$ & Spodopera exempta & $\begin{array}{l}\text { East and West } \\
\text { Africa }\end{array}$ & $\begin{array}{l}\text { Damage caused by larvae, } \\
\text { gregarious, move through at } \\
\text { high rates. }\end{array}$ \\
\hline Banks Grass Mite & $\begin{array}{r}\text { Oligonychus } \\
\text { pratensis }\end{array}$ & USA, India & $\begin{array}{l}\text { Suck sap from underside of } \\
\text { leaves, infestation spreads } \\
\text { upwards, web panicles, } \\
\text { lodging. }\end{array}$ \\
\hline Chinch Bug & Blissus leucopterus & North America & $\begin{array}{l}\text { Withdraw enormous quantities } \\
\text { of sap from stems, } \\
\text { reddened, weak, stunted, } \\
\text { lodge. }\end{array}$ \\
\hline Corn Earworm & Helicoverpa zea & Americas & $\begin{array}{l}\text { Feed on tender, folded leaves } \\
\text { and developing grain. }\end{array}$ \\
\hline Corn Leaf Aphid & $\begin{array}{l}\text { Rhopalsiphum } \\
\text { maidis }\end{array}$ & $\begin{array}{l}\text { Sorghum-growing } \\
\text { areas of world }\end{array}$ & $\begin{array}{l}\text { Suck plant juice, yellowish } \\
\text { mottling of leaves, } \\
\text { honeydew production } \\
\text { hinders harvesting. }\end{array}$ \\
\hline $\begin{array}{l}\text { Earhead (Christmas } \\
\text { Berry) } \\
\text { Webworm }\end{array}$ & $\begin{array}{l}\text { Cryptoblabes } \\
\text { gnidiella }\end{array}$ & India & $\begin{array}{l}\text { Destroy grain, webs of silken } \\
\text { thread on inside and outside } \\
\text { of head. }\end{array}$ \\
\hline Earhead Bug & $\begin{array}{l}\text { Calocoris } \\
\text { angustatus }\end{array}$ & India, Africa & $\begin{array}{l}\text { Infest panicles, suck sap from } \\
\text { developing grain, shriveled } \\
\text { and punctured grain. }\end{array}$ \\
\hline Earhead Webworm & Nola analis & Africa, Asia & $\begin{array}{l}\text { Larva feeds on grain in the } \\
\text { head. }\end{array}$ \\
\hline Fall Armyworm & $\begin{array}{l}\text { Spodoptera } \\
\text { frugiperda }\end{array}$ & $\begin{array}{l}\text { Southeastern USA, } \\
\text { tropical } \\
\text { America }\end{array}$ & $\begin{array}{c}\text { Feed on tender parts of whorl } \\
\text { leaves and developing grain } \\
\text { of panicle after emergence. }\end{array}$ \\
\hline Grasshoppers & $\begin{array}{l}\text { Oedaleus senega- } \\
\quad \text { lensis, Aliopus } \\
\quad \text { simulatrix }\end{array}$ & $\begin{array}{l}\text { Africa (southern } \\
\text { Sahara } \\
\text { borders), arid } \\
\text { parts of world }\end{array}$ & $\begin{array}{l}\text { Attacked at all plant stages, } \\
\text { most loss at seedling stage } \\
\text { or ripening of panicles. }\end{array}$ \\
\hline Greenbug & $\begin{array}{l}\text { Schizaphis } \\
\text { graminum }\end{array}$ & $\begin{array}{l}\text { Asia, Africa, } \\
\text { Australia, } \\
\text { America }\end{array}$ & $\begin{array}{l}\text { Injects toxins, reddish spots on } \\
\text { leaves, seedling pest, } \\
\text { damaging at heading stage. }\end{array}$ \\
\hline Maize Stalk Borer & Busseola fusca & Africa & $\begin{array}{l}\text { Deadhearts, growth retarded, } \\
\text { reduced grain and flowering. }\end{array}$ \\
\hline Oriental Armyworm & Mythimna separata & $\begin{array}{l}\text { Asia, Pacific } \\
\text { Islands, } \\
\text { Austrialia, Fiji, } \\
\text { New Zealand }\end{array}$ & $\begin{array}{l}\text { Feed on leaves leaving only } \\
\text { midrib, immature panicle } \\
\text { damage, entire crop loss if } \\
\text { heavy infestation. }\end{array}$ \\
\hline Shoot Bug & Peregrinus maidis & $\begin{array}{l}\text { India, Africa, West } \\
\text { Indies, } \\
\text { Bermuda, } \\
\text { Philippines }\end{array}$ & $\begin{array}{l}\text { Sap-sucking, stunted growth, } \\
\text { leaf death and sometimes } \\
\text { whole plant, prevent panicle } \\
\text { emergence. }\end{array}$ \\
\hline Shoot Fly & Atherigona soccata & $\begin{array}{l}\text { Semiarid tropics, } \\
\text { but not in } \\
\text { Americas and } \\
\text { Australia }\end{array}$ & $\begin{array}{l}\text { Larval feeding on central leaf, } \\
\text { deadheart symptom, } \\
\text { removed deadheart emits a } \\
\text { bad smell. }\end{array}$ \\
\hline
\end{tabular}


Table 16.1 (continued)

\begin{tabular}{|c|c|c|c|}
\hline Common name & Scientific name & $\begin{array}{l}\text { Geographical } \\
\text { distribution }\end{array}$ & $\begin{array}{l}\text { Feeding characteristics } \\
\text { and damage }\end{array}$ \\
\hline Sorghum Midge & $\begin{array}{l}\text { Contarinia } \\
\quad \text { sorghicola }\end{array}$ & $\begin{array}{r}\text { Worldwide except } \\
\text { Southeast Asia }\end{array}$ & $\begin{array}{l}\text { Larvae feeding on the ovary, } \\
\text { "blasted panicle." }\end{array}$ \\
\hline Sorghum Webworm & Nola sorghiella & $\begin{array}{l}\text { Humid south of } \\
\text { USA and } \\
\text { Central } \\
\text { America }\end{array}$ & $\begin{array}{l}\text { Feed on developing floral parts, } \\
\text { gnaw circular holes in the } \\
\text { seed. }\end{array}$ \\
\hline Spotted Stem Borer & Chilo partellus & $\begin{array}{l}\text { East Africa, Indian } \\
\text { subcontinent, } \\
\text { and the Far } \\
\text { East }\end{array}$ & $\begin{array}{l}\text { Small elongated windows in } \\
\text { young whorl leaves, bore } \\
\text { into the stem, deadheart } \\
\text { symptoms, chaffy seeds. }\end{array}$ \\
\hline Sugarcane Aphid & $\begin{array}{l}\text { Melanaphis } \\
\text { sacchari }\end{array}$ & $\begin{array}{l}\text { Asia, Africa, } \\
\text { tropical } \\
\text { America }\end{array}$ & $\begin{array}{l}\text { Prefers older leaves, sap-suck- } \\
\text { ing causing stunted plant } \\
\text { growth, drying of leaves } \\
\text { and death. }\end{array}$ \\
\hline Sugarcane Borer & $\begin{array}{l}\text { Diatraea sacchara- } \\
\text { lis, D. lineolata, } \\
\text { D. grandiosella }\end{array}$ & $\begin{array}{l}\text { North and South } \\
\text { America }\end{array}$ & $\begin{array}{l}\text { Bore up and down stalk, } \\
\text { lodging, panicle breakage. }\end{array}$ \\
\hline Sugarcane Borer & Eldana saccharina & $\begin{array}{l}\text { Africa south of the } \\
\text { Sahara }\end{array}$ & $\begin{array}{l}\text { Larvae hang by silken threads, } \\
\text { feed on leaves, bore midrib, } \\
\text { deadhearts. }\end{array}$ \\
\hline $\begin{array}{l}\text { Yellow Sugarcane } \\
\text { Aphid }\end{array}$ & Sipha flava & New World & $\begin{array}{l}\text { Prefers older lower leaves, } \\
\text { secretes potent toxin killing } \\
\text { seedlings, purpling/ } \\
\text { yellowing leaves, stunting, } \\
\text { lodging. }\end{array}$ \\
\hline
\end{tabular}

midge, Stenodiplosis sorghicola (Coquillett), shoot fly, Atherigona soccata (Rondani), or stem borer, Chilo partellus (Swinhoe), may occur perennially and dominate the pest control practices. In addition to the key pests, there are numerous insect species that can cause periodic plant damage and/or yield loss. Many other insects reported to damage sorghum are of regional/local importance or are only occasional pests that cause economic damage only in localized areas or only during some years.

Insect pests usually attack certain parts of sorghum plants (Teetes and Pendleton 2000). Insects attacking planted seeds and roots include wireworms, red fire ants, and white grubs. Insect pests of sorghum seedlings are cutworms, southern corn rootworm, chinch bug, and shoot fly. Insect pests often feeding on leaves and leaf whorls are greenbug, corn leaf aphid, yellow sugarcane aphid, shoot bug, oriental armyworm, whorl-infesting caterpillars, grasshoppers, banks grass mite, and fall armyworm. Sorghum panicle-feeding insects include sorghum midge, corn earworm, earhead worm, fall armyworm, sorghum webworm, and African head bug. Stalk-damaging insects are sugarcane borer, spotted stem borer, southwestern corn borer, Mexican rice borer, sugarcane rootstock weevil, pink borer, and African sugarcane borer. Insect pests of sorghum grain include grain weevil, grain borer, grain 
moth, grain beetles, flour beetles, and flour moth. Some insect pests feed on several plant parts. For example, fall armyworm larvae cause extensive defoliation of the crop and also burrow into the growing point (bud, whorl, etc.), destroying the growth potential of plants. Fall armyworms infest panicles after panicle emergence, in the same manner as corn earworm, Helicoverpa zea (Boddie). Some insect species also transmit viral diseases.

In spite of the impressive gains in sorghum production over the years, biotic and abiotic stresses continue to haunt sorghum farmers across the globe. Grain yields in the semiarid tropics (SAT) are generally low (500-800 kg ha-1) mainly due to insect pest damage (Sharma 1993). Accurate assessment of sorghum grain yield losses due to insect attack is scarce and difficult to obtain, however, annual losses to insect pests in sorghum have been estimated to be $\$ 1,089$ million in the semiarid tropics (ICRISAT 1992). In India, nearly $32.1 \%$ of the actual produce is lost due to insect pests (Borad and Mittal 1983), although they differ in magnitude on a regional basis.

As mentioned above, there are four devastating insect pests on sorghum, which cause severe damages to the crop and serious economic losses to sorghum producers. Sorghum midge, $S$. sorghicola, is one of the most ubiquitous and damaging insect pests attacking sorghum. It has been the subject of research since its first discovery in 1894 in Queensland (Tryon 1895). Estimates of annual cost to producers are \$28 million in Texas (Peterson et al. 1997), \$294 million in the semiarid tropics (ICRISAT 1992), and \$10 million in Australia (Henzell and Jordan 2009). A breeding program for resistance to sorghum midge began at Texas A\&M University soon after usable resistance sources of resistance were identified (Johnson et al. 1973), and similar research programs began at the Queensland Department of Primary Industries, Australia in 1975 (Henzell et al. 1980), and at ICRISAT Asia Center in India in 1980 (Sharma et al. 1994). In addition, the private sectors in Australia and the USA have also been breeding for resistance to sorghum midge.

The greenbug, S. graminum has been a major pest of sorghum since 1968 when biotype C was first reported (Harvey and Hackerott, 1969). Small grains, primarily wheat, act as winter hosts, and where the growing season of small grains does not overlap with that of sorghum, grasses such as Johnson grass, Sorghum halepense, serve as interim hosts. Sorghum growers have supported research on development of greenbug-resistant sorghums, and have benefitted from the resistant cultivars produced. The US and foreign consumers experienced economic benefits amounting to $\$ 248$ million and $\$ 274$ million annually, respectively (Eddleman et al. 1999).

Shoot fly, A. soccata is an important pest of sorghum in Asia, Mediterranean Europe, and Africa. Annual losses have been estimated at \$200 million. In India, shoot fly damage in sorghum at times results on $90 \%$ reduction in grain yield, and $45 \%$ of fodder yield, (ICRISAT 1992). The severity of damage by spotted stem borer, $C$. partellus can result in severe loss of crop stand when seedlings are attacked. It is a serious pest in Asia, and East and southern Africa. Maize stalk borer, B. fusca, is a major pest in the African highlands. The stem borers can also infest the plants at a later stage, causing stem tunneling, which weakens the stem and results in stem 
breakage and unfilled grains. Losses caused by stem borers have been reported to be between 5 and 15\% in West Africa, and 18 and 27\% in East Africa. In India, reported losses range as high as $55-83 \%$ on certain susceptible hybrids and varieties during severe infestations (ICRISAT 1989). In the semiarid tropics, stem borers cause an annual loss of \$334 million (ICRISAT 1992).

\section{Sorghum Plant Response to Insect Attack}

There are many harmful insects that coexist with plants in various agro-ecosystems. During their coevolution with plants, insects have evolved the ability to search their host plants for feeding and oviposition using physical and/or chemical cues from the host plants. During the long course of interactions, herbivorous insects developed a compatible relationship with their plant hosts, so they are able to live on those plants. Based on their interactions with the host plants, there are two types of insects: generalists and specialists. Generalist herbivorous insects have a wide host range, being able to feed on many species of plants; whereas specialists have a narrow host range, attacking only one or a few plant species within the same family. Greenbug and stem borers are good examples of generalist insect pests, and shoot fly and midge as specialists on sorghum. Plant injury occurs when insect feeding causes abnormal metabolism and function, leading to irreversible physical or chemical changes in plant. In general, plant injury is expressed as defoliation, reduction in growth, yield loss, or poor grain quality.

On the contrary, plants have also developed their defense systems (i.e., host plant resistance [HPR]) to counteract herbivore attack. Defense is costly; thus discerning insect feeding from causal mechanical wounding and quickly deploying increased levels of defensive compounds that are critical to effectively battle insect pests infesting sorghum plants (Huang 2007; Park et al. 2006). As a result, insect-resistant plants can alter the relationship that an insect pest has with its plant host. The interactions between the insects and plants are dependent upon different resistance mechanisms. Three types (i.e., mechanisms) of resistance were described by Painter (1951), including antibiosis, antixenosis (non-preference), and tolerance. Antibiosis affects the biology of the insect so that pest abundance and subsequent damage is reduced as compared to the one that would have occurred normally if the insect feeds on a susceptible crop variety. Antibiosis resistance often results in increased mortality or prolonged development and rescued fecundity. Antixenosis affects the behavior of an insect pest and usually is expressed as non-preference of the insect for the resistant plant as compared to a susceptible plant. Tolerance is the capability of a host plant to withstand or recover from the damage caused by insect pest abundance that would damage a susceptible plant. Tolerance is a plant response to an insect pest and differs from antibiosis and antixenosis resistance as to how it affects the insect-plant relationship. Antibiosis and antixenosis components of resistance induce an insect response when the insect attempts to use the resistant plant for food, oviposition, or shelter. Antibiosis, antixenosis, and tolerance are the major 
components of resistance against sorghum stem borer, $C$. partellus and maize stalk borer, B. fusca (van den Berg et al. 1994; Sharma and Nwanze 1997). Greenbug resistance in sorghum has often been explained as tolerance, but our recent studies with diverse resistance sorghum germplasm suggested that both antibiosis and antixenosis are present in some resistant lines of sorghum (Huang, unpublished data).

Host plant defenses can also be described as constitutive or inducible. Constitutive defenses include physical and chemical barriers or traits that are formed regardless of the presence of insects. For instance, some plants form many external structural barriers such as sharp prickles, thorns, trichomes, and cuticles that restrict insect attack and feeding. Other plants produce and release defense compounds such as resins, lignins, and wax that alter the texture of the plant tissues which discourage herbivory. Some sorghum varieties are able to synthesize cyanogenic glycosides and store them in inactive forms in plant vacuoles. They become toxic when herbivores eat the plant and break the cell membranes, and thus allowing the glycosides to come into contact with enzymes in the cytoplasm that catalyze reactions releasing hydrogen cyanide, which blocks cellular respiration of the insects. Phenolics are also shown to have negative effects on herbivores, while the condensed tanninspolymers composed of 2-50 (or more) flavonoid molecules, can inhibit herbivore digestion by binding to consumed plant proteins. Constitutive and inducible defenses are achieved through similar means, but differ in the sense that constitutive defenses are expressed before insect attack, while inducible defense is activated only after a plant is attacked by an insect.

HPR has often been used for successful management of several insect pests in sorghum, but certain limitations and problems will always beset any insect control program, and HPR is no exception. Although several sources of resistance have been identified against greenbug, shoot fly, spotted stem borer, sorghum midge, and head bugs in sorghum (Sharma et al. 1988a, b, 1992, 2003; Kumari et al. 2000; Huang 2004, 2011), only a few of them are being deployed in the development of insect-resistant varieties, as it takes a long time and needs a great deal of expertise and resources. In a complementary approach, efforts have been made in the past toward the development of insect-resistant sorghums using biotechnological approaches, discussed in a later section. Good examples of the recent advances in development of insect-resistant sorghums include the effects of cytoplasmic male-sterility on expression of resistance to insect pests, transfer of insect-resistance genes in cytoplasmic male-sterile (CMS/A), maintainer (B), and restorer $(\mathrm{R})$ lines, diversification of CMS systems, and development of insectresistant transgenic sorghums.

\section{Identification of Resistance Sources and Utilization of HPR}

HPR is a pest management method that utilizes the plant's own defense mechanisms against an insect pest. The prerequisite for this approach is to identify sources of resistance. As sorghums are native to the warm environments, where 
their associated herbivores and entomophages have coevolved, there is an opportunity to search for insect-resistance sources in the diverse sorghum germplasm. Sorghum genetic resources are conserved at many centers around the world as detailed by Kimber (2012).

Accessions of these sorghum seed collections were obtained from all geographic regions in the world, from tropical to temperate zones, from high and low elevations, as well as from those grown in different seasons of the year. Thus, any resistance sources can probably be found in such world sorghum germplasm collections, although much of them have not yet been evaluated for resistance to insects. Greenbug is a key pest of sorghum in most areas of the USA where the crop is grown, especially in the Great Plains. To manage this damaging pest, sources of resistance were found in sorghum germplasm in the late 1960s (Young and Teetes 1977), and since then efforts in finding new sources continue at many public research laboratories (Peterson et al. 1997; Huang 2006). Releases of resistant breeding materials have been made to commercial seed companies. Thus, incorporation of greenbug resistance into elite parental lines and hybrids has been the goal of every sorghum breeding program in the USA. However, the effectiveness of these resistant germplasms has been limited by the tremendous diversity of virulence genes (i.e., biotypes) that exists within greenbug populations (Burd and Porter 2006). The original biotype to attack sorghum was biotype $\mathrm{C}$, and since then, 10 additional biotypes have been detected, and three of these (E, I, and K) damage sorghum (Peterson et al. 1997). Several examples of successful deployment of resistant cultivars can be cited, but resistance is oftentimes short-lived due to the tremendous diversity of biotypes in the target pest populations and evolution of virulence. New sources of resistance to these key pests must be found continuously and incorporated into high-performance breeding lines for cultivar/hybrid development. Continuous improvement in crop defense against the new biotypes of the greenbug is dependent on the availability of diverse genetic resources and judicious use of effective sources of resistance. At present, over 40,000 sorghum germplasm accessions, including many exotic sources, have been evaluated for their response to greenbug feeding in the greenhouse at the USDA-ARS Plant Science Research Laboratory, Stillwater, Oklahoma, leading to the identification of new sources of resistance and novel genetic resistance in sorghum (Huang 2011).

In India, over the past five decades, a large proportion of the world sorghum germplasm collection has been evaluated for resistance to insect pests, and a number of lines with resistance to the major insect pests have been identified (Sharma et al. 1992, 2003). Large-scale screening of the sorghum germplasm at ICRISAT has resulted in identification of several lines with reasonable levels of resistance to shoot fly, stem borer, midge, and head bugs. Sources of resistance to insects in sorghum have been used in the breeding program, and many varieties with resistance to insect pests have been developed. However, cultivars with resistance to insect pests are cultivated by the farmers only on a limited scale due to over emphasis on grain yield as a criterion to release cultivars by the national programs. Now having achieved a plateau in grain yield in sorghum, it is important that insect resistance be used as one of the criteria to identify varieties and hybrids for use by the farmers for 
sustainable crop production. To effect this change, the research needs to be driven more by the ground reality than by perception.

Identification and transfer of insect resistance from the wild relatives of sorghum have been much less successful than that of resistance to diseases. Nonetheless, the wild relatives of sorghum provide sources of diverse genes for resistance to insect pests (Sharma et al. 2005). The vast and largely underutilized pool of desired genes/ traits existing in the wild relatives of cultivated sorghum will provide a huge new resource of genetic resistance to promote the next phase of sorghum genetic improvement for insect resistance.

Levels of resistance to sorghum shoot fly (A. soccata) and stem borer (C. partellus) in the cultivated sorghum are low to moderate (Sharma et al. 1992, 2003). Therefore, it may be important to identify wild relatives of sorghum with high levels of resistance to insect pests (Venkateswaran et al. 2009). Wild species of sorghum (Sorghum purpeosericeum and S. versicolor) possess very high levels of resistance to shoot fly (Mote 1984). Venkateswaran (2003) identified several species of sorghum with high levels of resistance to A. soccata, with resistance levels close to immunity under field conditions. Accessions belonging to Parasorghum (S. australiense, S. purpureosericeum, S. brevicallosum, S. timorense, S. versicolor, S. matarankense, and S. nitidum) and Stiposorghum (S. angustum, S. ecarinatum, S. extans, S. intrans, S. interjectum, and S. stipoideum) did not show any shoot fly damage under multi-choice conditions in the field (Venkateswaran et al. 2009). Heterosorghum (S. laxiflorum) and Chaetosorghum (S. macrospermum) showed very low damage by the sorghum shoot fly. Within section Sorghum, the four wild races belonging to S. bicolor subsp. verticilliflorum (aethiopicum, arundinaceum, verticilliflorum, and virgatum) were highly susceptible to shoot fly, as was $S$. halepense. Fifteen species of wild relatives of sorghum have shown high levels of resistance to spotted stem borer, C. partellus, under artificial infestation in the field (Venkateswaran 2003). Species belonging to Heterosorghum (S. laxiflorum), Parasorghum (S. australiense, S. purpureosericeum, S. versicolor, S. matarankense, S. timorense, S. brevicallosum, and S. nitidum), and Stiposorghum (S. angustum, S. ecarinatum, $S$. extans, $S$. intrans, $S$. interjectum, and $S$. stipoideum) showed little damage by the spotted stem borer larvae, except for one accession of Heterosorghum, which showed 2\% deadhearts. In contrast, section Chaetosorghum (S. macrospermum) was highly susceptible to stem borer damage. Within section Sorghum, the four wild races of S. bicolor subsp. verticilliflorum (races arundinaceum, aethiopicum, verticilliflorum, and virgatum) were highly susceptible to stem borer damage, as was $S$. halepense. Sorghum midge, S. sorghicola females did not lay any eggs in the spikelets of wild relatives of sorghum such as $S$. angustum, S. amplum, and S. bulbosum compared to 30 eggs in S. halepense under no-choice conditions (Sharma and Franzmann 2001). Larger numbers of sorghum midge females were attracted to the odors from the panicles of $S$. halepense than to the odors from panicles of S. stipoideum, S. brachypodum, S. angustum, S. macropsermum, S. nitidum, S. laxiflorum, and S. amplum. The accessions belonging to the secondary gene pool with diverse mechanisms of resistance can be crossed with cultivated sorghum, while those belonging to the tertiary gene pool may require 
application of embryo rescue techniques to transfer resistance genes from the wild relatives into cultivated sorghums.

Use of insect-resistant crop varieties is economically, ecologically, and environmentally advantageous. Economic benefits occur because crop yields are saved from loss due to insect pests and money is saved by not applying insecticides that would have been applied to susceptible varieties. In most cases, seed of insectresistant cultivars costs no more, or a little more, than for susceptible cultivars. Ecological and environmental benefits would certainly arise from increases in species diversity in the agro-ecosystem, in part because of reduced use of insecticides.

\section{Conventional Approaches of Insect Pest Management}

The primary goals of conventional breeding of sorghum have been focused on the improvement of the crop with higher yield and better quality. Once this is achieved, resistance traits can be incorporated, provided the methods for introducing the resistance can be readily integrated into the breeding programs. Human involvement in the improvement of sorghum began with identification and selection of plants with desirable characteristics for a better production. These new genotypes arose from random outcrosses or mutations that were fixed due to the self-pollination of the new type. Thus, a number of sorghum cultivars and elite breeding lines characterized for resistance to major insects have been developed through conventional breeding methods (Rooney 2004). In such breeding approaches, particularly in breeding insect resistance, sorghum breeders usually search for genetic variability for insect resistance and then incorporate the desired traits into breeding lines, leading to the development of resistant commercial cultivars or hybrids. Since sorghum is a self-pollinated species, most breeding methodologies (both cultivar and hybrid) are based on the production of segregating populations followed by selection in segregating populations. The selections are usually allowed to self-pollinate during selection to produce homozygous uniform lines (i.e., pure-line cultivars). In hybrid breeding programs, these lines will be test crossed to measure their value as a parental line. Later, the use of hybrid vigor is facilitated by cytoplasmic malesterility. Evidently, incorporation of insect resistance into elite parental lines and hybrids has been the goal of many sorghum breeding programs in the USA and elsewhere. The goal of most population improvement programs is to accumulate favorable alleles for the traits of interest while maintaining as much genetic diversity as possible. Wide hybridization involving crosses between cultivated sorghum and un-adapted sorghum germplasm lines or related wild species is also used in some breeding programs. The benefits of wide hybridization include broadening the genetic diversity of the crop and utilizing the newly identified resistance genes in distantly related sources.

Insect pests of sorghum should be managed by actions that prevent insects from becoming abundant enough to cause economic damage. Management actions include using nonchemical and chemical methods. Cultural and biological 
management methods are nonchemical methods imposed to avoid insect pests, suppress insect pest abundance or rate of increase, delay the time when insect pests reach damaging abundance levels, or increase plant tolerance to insect pests. Because nonchemical management methods are imposed to avoid or prevent insect pest damage, the decision to use these methods must be made before an insect pest problem occurs, and often even before the crop is planted. Chemical management methods involve use of insecticides to kill insect pests. Insecticides have a rapid and curative action but are costly and may cause negative ecological and environmental consequences. Therefore, their use must be justified based on actual measurement of insect abundance and damage. Integrated pest management (IPM) involves the use of a combination of management methods in a strategy to maintain insect pest abundance or damage below levels that cause economic loss. IPM has been a practical approach to dealing with insect pests of sorghum.

To manage insect pests of sorghum, integrated pest management systems depend on an array of different approaches, such as planting time to avoid infestation, crop rotation, biological control by using natural enemies, chemical control, etc. In cases where cultural control methods are not always effective and pesticides are either not available or economically feasible, the development and deployment of genetically resistant crops in an integrated pest management production system is an effective, economical, and environmentally sound approach (Sharma 1993). In addition, breeding for crop resistance to insect pests was considered to be a safe and inexpensive insect control method, highly applicable to small-farm conditions and easily accepted by sorghum producers. In recent years, research has focused on identification of insect-resistant sources and various sorghum improvement programs have intensified their efforts to breed insect-resistant and stable-yielding varieties and hybrids as these are likely to be more critical for sustainable production.

Cytoplasmic male-sterility has an effect on expression of resistance to insect pests. Most of the sorghum hybrids grown across world are based on the A cytoplasm, which has been found to be highly susceptible to insect pests (Sharma 2001; Sharma et al. 2004; Dhillon et al. 2008). Ross and Kofoid (1979) have also reported that the Kansas lines KS 34 to KS 39 based on Kansas CMS system are as susceptible as CKA (Combine Kafir-based CMS lines) to the greenbug, S. graminum. Sharma et al. (1994) recorded low damage by the sorghum midge, and reduced midge emergence on midge-resistant B-lines as compared to corresponding A-lines. However, no differences were found for midge damage or adult emergence between midge-resistant and -susceptible A-lines. Midge-resistant CMS x susceptible restorer-based hybrids were less susceptible to $S$. sorghicola damage than susceptible CMS $\times$ susceptible restorer-based hybrids (Johnson 1977; Sharma et al. 1996). The expression of non-preference and antibiosis components of resistance to southwestern corn borer, Diatraea grandiosella Dyar, and sugarcane borer, Diatraea saccharalis Fab., was higher in resistant inbred line-based hybrids, CML 67 ×CML 135 and CML $139 \times$ CML 135 than the inbreds (Kumar and Mihm 1996). These hybrids also suffered low leaf and stalk damage, and grain yield loss in comparison to the susceptible hybrid Ki $3 \times$ CML 131. The oviposition and deadheart formation on main plants and tillers of sorghum by the shoot fly were significantly lower on 
maintainer lines compared to the CMS lines (Dhillon et al. 2006a). Larval development was prolonged and pupal mortality was greater on maintainer lines than on the CMS lines, while pupal weights and fecundity were greater on the CMS lines (Dhillon et al. 2006a). The maintainer lines showed better recovery resistance than the CMS lines, but such differences were more apparent in the shoot flyresistant CMS and maintainer lines than in the shoot fly-susceptible CMS and maintainer lines. Furthermore, the $\mathrm{A}_{4} \mathrm{M}$ cytoplasm has been found to be comparatively less susceptible to $A$. soccata damage than the $\mathrm{A}_{1}, \mathrm{~A}_{2}, \mathrm{~A}_{3}, \mathrm{~A}_{4} \mathrm{G}$, or $\mathrm{A}_{4} \mathrm{VzM}$ cytoplasms (Dhillon 2004; Dhillon et al. 2005). Expression of morphological traits such as leaf glossiness, trichomes, and leaf surface wetness was better in the maintainer lines as compared to the CMS lines (Dhillon et al. 2006c). The shoot bugand sugarcane aphid-resistant CMS lines suffered more damage than the B-lines, while such differences were not apparent in case of susceptible CMS and maintainer lines (Dhillon et al. 2006b). The stem borer-resistant CMS and maintainer lines experienced similar levels of deadheart formation, while the stem borer-susceptible maintainers suffered more damage than the CMS lines (Dhillon et al. 2006b), indicating that the expression of resistance may be influenced by the interaction of factors in the cytoplasm of maintainer lines with the nuclear genes. Hybrids based on shoot bug, sugarcane aphid, midge, and shoot fly-resistant CMS and restorer lines suffered less damage than the hybrids based on susceptible CMS and resistant or susceptible restorer lines, suggesting that expression of resistance to these insects is influenced by the genetic background of the CMS lines (Sharma et al. 2004; Dhillon et al. 2006d; Sharma et al. 2006). However, the hybrids based on stem borer-resistant or -susceptible CMS lines with resistant restorers showed significantly lower deadheart formation as compared to the hybrids based on stem borer-resistant or susceptible CMS lines and -susceptible restorers, suggesting that restorer lines exercised a greater influence on expression of resistance to stem borer in sorghum (Dhillon et al. 2006b). Similar results have also been reported for expression of resistance to stem borers, C. partellus and B. fusca in maize (Kumar 1993). Dhillon et al. (2008) suggested that the genetic background of CMS, cytoplasmic factors, the interactions of the factors in the cytoplasm of maintainer lines with the nuclear genes and the restoration abilities of the restorers, influence the expression of resistance to insect pests in cereals depending on the crop and the insect species involved, and therefore, there is a continuing need to evaluate different cytoplasms for their effects on cultivar susceptibility to insect pests before being finally deployed in crop improvement programs. Also, there is an urgent need to convert various sources of resistance to insect pests into CMS, maintainer, and restorer lines, so as to be able to develop hybrids with increased levels and diverse mechanisms of resistance to target pests, which can be used by the public institutions and private seed industry to develop insect-resistant hybrids. Pedigree method is the most suitable and easy-to-operate breeding method for development of insect-resistant restorer and maintainer lines.

The commercial sorghum hybrids produced so far across the world are based on the single cytoplasm designated as $\mathrm{A}_{1}$ (Reddy and Stenhouse 1994; Moran and Rooney 2003), except in China. However, based on experience in other crops (Tatum 
1971), and the available information in sorghum, CMS lines are more susceptible to insect pests. Exclusive use of the $\mathrm{A}_{1}$ cytoplasm as a source of male-sterility in commercial hybrid seed for multiplication of sorghum might restrict nuclear diversity of male-sterile (A) as well as restorer (R) lines, and thus, increase vulnerability to other biotic and abiotic stresses. Therefore, as a contingency plan to prevent such eventualities and to broaden the genetic base, several non-milo CMS systems designated as $A_{2}, A_{3}, A_{4}(V z M), A_{4}$ (Maldandi), and $A_{4}$ (Guntur) were identified and developed (Schertz 1994) for use in hybrid breeding programs. Several nuclear genes are known to control expression of CMS and thus different CMS types can be distinguished through restoration patterns in testcrosses and anther morphology (classical method) or using molecular markers. Differentiation of cytoplasmic types, in addition to male-sterility influences, is a prerequisite for their efficient utilization to diversify the CMS-base of hybrids. Further, deployment of different CMS systems in different genetic backgrounds is necessary to diversify CMS systems in order to nullify the CMS effect and develop pest-resistant hybrids.

\section{Genomic Tools for Genetic Analysis of Insect Resistance and Marker-Assisted Breeding}

To facilitate the identification and isolation of chromosomal regions or genes involved in adaptation to adverse environments or resistance to biotic stresses, genome resources enabling analysis of sorghum trait loci have been developed. Genetic mapping of sorghum based on DNA markers began almost two decades ago and the first sorghum maps were based largely on DNA probes from maize (Hulbert et al. 1990). Although several versions of sorghum maps have been produced, they were not complete until the maps of Pereira et al. (1994) and Chittenden et al. (1994), which contain all ten linkage groups, known lately as ten chromosomes (Kim et al. 2005). Both of the later maps were constructed with RFLP markers in $\mathrm{F}_{2}$ populations of relatively small size. After that, a more detailed RFLP-based map (Bowers et al. 2003), an AFLP-based map (Klein et al. 2000), and an integrated RFLP and SSR linkage map (Bhattramakki et al. 2000) were developed for sorghum.

Recently, simple sequence repeats (SSRs) or microsatellites have become the most important DNA marker technology as they proved to be a more dependable, rapid, and inexpensive tool for plant genotyping (Yang et al. 1996). We have recently constructed a detailed SSR-based genetic map for sorghum (Wu and Huang 2007), in which the mapped SSR loci distributed throughout all ten chromosomes and spanned a distance of $997.5 \mathrm{cM}$. With rapid increase in the availability of cDNA clones and expressed sequence tags (ESTs), we also took the in silico mining approach for the development of EST-SSRs (i.e., SSRs derived from ESTs or cDNA sequences). From the available 25,456 ESTs or cDNA sequences, we were able to develop 2,680 EST-SSRs (Huang 2008). These newly developed sorghum ESTSSR markers represent an additional resource for genetic mapping, comparative 
genomics, as well as evaluation of colocation between QTLs and functionally associated markers in target species. Among these newly identified markers, a sub-set of 200 randomly selected EST-SSR markers was examined for the transferability to related cereal crops, showing their potential as molecular markers in maize, sugarcane, rice, wheat, and barley. EST-SSR markers offer the potential to cover the gene-rich regions of the entire nuclear genome and to fill gaps in linkage maps using comparative genomic information (Ramu et al. 2009).

With the availability of dense linkage maps of the sorghum genome, progress in the identification of genes or QTLs linked to plant resistance to diseases, insects, and abiotic stresses has been made. For example, greenbug aphid has been the most damaging insect pest of sorghum in the USA and often causes severe crop damage and significant economic loss. Using SSR markers, we have identified major QTLs conferring resistance to greenbug biotype $\mathrm{E}$ (Wu et al. 2007) as well as to greenbug biotype I (Wu and Huang 2008). A separate study reported that two genetic regions located on separate linkage groups were found to be associated with midge resistance and explained $12 \%$ and $15 \%$ of the total variation, respectively (Tao et al. 2003). At ICRISAT, mapping populations have been phenotyped and genotyped for sorghum shoot fly $(296 \mathrm{~B} \times$ IS 18551 and BTx $623 \times$ IS 18551$)$, spotted stem borer, sorghum midge, and aphid (ICSV $745 \times$ PB 15881-3). Genetic linkage maps based on these populations have been constructed to identify QTLs associated with resistance to these insects. Polymorphic simple sequence repeat (SSR) loci associated with resistance to shoot fly and the traits associated with resistance to this insect have been identified (Folkertsma et al. 2003; Dhillon et al. 2006e; Satish et al. 2009; Aruna et al. 2011). These QTLs are now being transferred into the locally adapted hybrid parental lines via SSR-based marker-assisted selection. QTLs associated with resistance to sorghum head bug (Eurystylus oldi Poppius) have also been identified (Deu et al. 2005). In addition, Satish et al. (2009) reported that QTL identified in this study correspond to QTL/genes for insect resistance at the syntenic maize genomic regions, suggesting the conservation of insect-resistance loci between these crops.

In general, it takes five to six generations to transfer a trait within a species into high-yielding, locally adapted cultivars through conventional breeding, and in this way, one has to evaluate a large number of progenies to be able to select the plants with the appropriate combination of traits. Fortunately, use of DNA markers for indirect selection offers great potential gains for quantitative traits with low heritability, as these are the most difficult characters to work with in the field using direct phenotypic selection. The effectiveness of a marker-assisted selection (MAS) can only be as good as the quality of the phenotypic data on which the development of the marker was based. It is hoped that MAS will allow rapid introgression of the resistance genes, and ultimately gene pyramiding, into the high-yielding varieties and hybrids. No doubt, all of the resultant information from the above-mentioned studies will facilitate the early selection of breeding lines through marker-assisted selection and cloning of the important resistance genes for sorghum improvement via the map-based cloning method. 


\section{Gene Expression Analysis and Gene Discovery}

In addition to constitutive defenses, initiation and utilization of specific defense responses to attacking insect pests are important strategies for plant persistence and survival. Inducible defenses of plants consist of three steps: perception of herbivore, signal transduction, and biosynthesis of defensive products (Wu and Baldwin 2010). A wide range of inducible genes has been identified in plants based on endogenous chemical signals such as phytohormones, response to insect attack, or wounding. Chemically induced expression systems or "gene switches" enable the temporal, spatial, and quantitative control of genes introduced into crop plants, or those that are already present in the plants. The best-studied system utilizes pathogenesisrelated protein-1a ( $P R$ 1-a) gene expression in tobacco (Uknes et al. 1993). The $P R$ 1- $a$ mRNA levels can also be induced by exogenous application of salicylic acid (Ward et al. 1991). Peptide hormones also induce production of proteinase inhibitors. Systemically induced responses are modified through synthesis and action of jasmonic acid via its lipid precursor, e.g., linoleic acid in tomato. Application of exogenous jasmonate induces the production of proteinase inhibitors. Enhanced resistance in transgenic rice plants by application of methyl jasmonate and abscisic acid has been observed (Xu et al. 1993).

The mechanisms of inducible plant defense responses are based on changes in gene expression. The rapid pace of advances into the molecular events of plant perception of pathogens has been particularly inspiring for the study of how plants perceive insect attack, although the same type of research is more advanced in the study of plant diseases. Microarray experiments for analyzing plant responses to insect attack have already shown promise for functional characterization of important processes such as plant defense. Zhu-Salzman et al. (2004) evaluated the transcriptional changes in a sorghum cultivar by comparing expression patterns of 672 cDNAs in the seedling tissues before and after infestation by greenbug or following treatment with defense signal components such as salicylic acid (SA) or methyl jasmonate (MJ). Their results indicated that activation of certain transcripts regulated exclusively by greenbug infestation was observed, and the expression patterns may represent unique signal transduction events independent of $\mathrm{MJ}$ - and SA-regulated pathways. More recently, we have examined the transcriptional changes in a parallel system, greenbug-resistant and -susceptible genotypes of sorghum, leading to detection of the abundance of the transcripts corresponding to 2,304 sorghum genes during the infestation by virulent greenbug biotype I (Park et al. 2006). The experiments showed comprehensive gene activation resulting from up-regulating, or activating existing defense pathways in sorghum seedlings in response to greenbug feeding. Among the induced genes identified in this study, 38 genes exhibited threefold or higher abundance in their expression, and 26 genes were significantly reduced. These cutting-edge technologies can enhance the understanding of plant defense mechanisms against insect pests, and also accelerate the identification of resistance genes or specific targets for improvement of plant resistance for integrated pest management in agriculture. 


\section{Transgenic Approaches of Insect Resistance in Sorghum}

Plant biotechnology has become a promising tool for agricultural revolution, providing new solutions to age-old agricultural practices. Especially, significant advances in gene identification and gene transfer techniques allow the incorporation of beneficial genes for specific agronomic traits into diverse crop plants. Today these new tools enable plant breeders to design new varieties by installing desired foreign genes, such as insect- and disease-resistance genes, into existing commercial lines or elite breeding lines in a considerably short period of time. During the last decade, many of the world's most important crops (including wheat, maize, rice, soybean, and cotton) had already been engineered with increased resistance to insects and diseases (Sahrawat et al. 2003). Similar research has already been attempted in sorghum. Early research activities in sorghum transformation focused on developing gene transfer systems; thus successful genetic transformation systems were developed using either particle bombardment (Casas et al. 1993) or Agrobacterium-mediated transformation (Zhao et al. 2000). Though both Agrobacterium-mediated and particle bombardment transformation systems are successful in sorghum, the most effective method to date is Agrobacterium-based transformation, with a transformation efficiency of 2.1-4.5\% (Zhao et al. 2000; Gao et al. 2005; Howe et al. 2006). Further information on the current status of sorghum transformation is provided elsewhere in this volume (Tejinder et al. 2012).

Today, sorghum producers face a major threat to their crops from insect pests worldwide. Given the wide host range of some of the insect pests, and low levels of resistance in the cultivated germplasm against major sorghum pests such as stem borers, head bugs, and armyworms, it will be highly desirable to combine conventional plant resistance with novel genes from other sources such as Bacillus thuringiensis $(\mathrm{Bt})$ toxic proteins, protease inhibitors, or plant lectins. Streamlined sorghum transformation could help in production of transgenic plants with improved resistance to important insect pests. Sorghum plants having the crylAc gene have been developed under the control of a wound-inducible promoter from a maize protease inhibitor gene ( $m p i$ ) for resistance to spotted stem borer, C. partellus (Seetharama et al. 2001; Harshavardhan et al. 2002; Girijashankar et al. 2005). Feeding by the neonate larvae of $C$. partellus on the leaf discs from transgenic plants was $60 \%$ lower compared to that on the nontransgenic control plants, and the weight gain by the larvae was reduced by $36 \%$, which could be due to low levels of Bt protein expressed in sorghum leaf tissues, as it was $1-8 \mathrm{ng} \mathrm{g}^{-1}$ of fresh leaf tissue. The larval mortality was $40 \%$ more in the larvae fed on leaf discs from transgenic plants compared to that on the nontransgenic control plants. Thus, combining transgenic resistance to insects with the conventional plant resistance will make HPR an effective weapon for pest management in sorghum. More recently, Kosambo-Ayoo et al. (2011) reported that sorghum was transformed with the chitinases and chitosanases genes isolated from Trichoderma harzianum. Seedlings from a transgenic line were found to be significantly more tolerant to anthracnose than the parent wild 
type. The above successful examples demonstrate that transgenic technology can pyramid resistance genes to multiply the effectiveness of beneficial genes in sorghum crops with multiple resistances to insect pests and diseases.

As the transformation systems are available in sorghum, now the speed of gene discovery is the bottleneck for molecular breeding in sorghum. It is noteworthy that some secondary plant metabolites such as flavonoids have been implicated in HPR to insects in sorghum. Many compounds of the flavonoid biosynthetic pathway accumulate in response to biotic and abiotic stresses (Heller and Forkman 1993). Genetic engineering offers the opportunity to change the metabolic pathways to increase the amounts of various flavonoids, which play an important role in HPR to insect pests (Zhuang et al. 2011). Biotechnology also offers the opportunity to increase the production of secondary metabolites in plants to increase the levels of resistance to insect pests or inhibit the production of toxic metabolites such as $\mathrm{HCN}$ in forage sorghum. Thus, combining transgenic resistance to insects with conventional plant resistance will make plant resistance an effective component for pest management in sorghum.

\section{Summary}

Sorghum has an advantage over other grain crops because it can withstand relatively harsh, hot, dry climates, but responds well to favorable production conditions and irrigation. Thus, sorghum has a reduced vulnerability to climate change, becoming more important in future agriculture as a drought-tolerant, fast-growing crop, which can thrive and yield relatively well even with high water scarcity within the shortened length of the growing seasons, as it matures before the depletion of soil moisture, thereby reducing the threat from dry spells (Dar 2009). In addition, sorghum, a leading and cost-effective bioenergy crop, is poised to have an important role in crop production worldwide as farmers are willing to grow sorghum as a cellulosic bioenergy crop in order to help meet the demands of renewable fuels to produce "next generation" fuels. However, insect pests will be a major limiting factor in sustainable production of sorghum in the future. Among the major insect pests that limit its production in various geographic areas are greenbug, midge, shoot fly, stem borer, and head worms.

HPR is one of the most economic means of controlling insect pests without the undesirable effects of pesticides. The utilization of natural resistance for pest management has been successful in the past and some of the resistances have been transferred into commercial cultivars and hybrids. Continuous research efforts on identification of new sources of resistance to the major pests of sorghum and breeding for these types of resistance are major research objectives, along with basic studies on insect-host plant relationships for a better understanding of the nature of resistance. In germplasm evaluation for pest resistance, sorghum researchers need to improve precision of screening and selection criteria for resistance to insect pests in many cases. Genetic resistance in sorghum, wherever available, should be combined 
with other desirable plant characters, such as high yield, good quality, disease resistance, and should provide the basic foundation on which to build integrated pest management systems. A promising strategy for sorghum improvement should be based on gene pyramiding and development of cultivars with multiple resistances to insect pests and diseases. There is an urgent need to transfer various insect-resistance genes into CMS, maintainer, and restorer lines, so as to be able to develop hybrids with increased levels, and diverse mechanisms of resistance to target pests.

Despite progressing beyond basic research involving the development of transformation methods for introducing useful genes to the sorghum genome, gene transfer technology in sorghum is still at a juvenile stage. Protocols need to be optimized in order to develop simple procedures with improved transformation efficiency. Transgenic technology will certainly make it easier to transfer resistance genes from wild relatives or other sources and can assist in the production of agronomically desirable crops that have, for example, improved ability to defend themselves against insect pests.

Genomic technologies have aided tremendously in identifying loci or genomic regions associated with insect resistance in most crop plants including sorghum. These genomic tools and molecular markers not only promise to increase our knowledge of mechanisms underlying host resistance to insect pests in sorghum, but also facilitate the marker-assisted breeding in our future sorghum breeding programs. All above-mentioned research approaches promise to facilitate development of insect-resistant cultivars and hybrids of sorghum. However, the complexity in improving levels of pest resistance requires collaborative efforts between research institutions and the sorghum industry as well as international cooperation in utilization of emerging knowledge and technologies to enhance the global efforts in insect pest management.

The US Department of Agriculture (USDA) prohibits discrimination in all its programs and activities on the basis of race, color, national origin, age, disability, and where applicable, sex, marital status, familial status, parental status, religion, sexual orientation, genetic information, political beliefs, reprisal, or because all or part of an individual's income is derived from any public assistance program. (Not all prohibited bases apply to all programs.) Persons with disabilities who require alternative means for communication of program information (Braille, large print, audiotape, etc.) should contact USDA's TARGET Center at (202) 720-2600 (voice and TDD). To file a complaint of discrimination, write to USDA, Director, Office of Civil Rights, 1400 Independence Avenue, S.W., Washington, DC 20250-9410, or call (800) 795-3272 (voice) or (202) 720-6382 (TDD). USDA is an equal opportunity provider and employer.

\section{References}

Aruna C, Bhagwat VR, Madhusudhana R, Sharma V, Hussain T, Ghorade RB, Khandalkar HG, Audilakshmi S, Seetharama N (2011) Identification and validation of genomic regions that affect shoot fly resistance in sorghum [Sorghum bicolor (L.) Moench]. Theor Appl Genet 122:1617-1630

Bhattramakki D, Dong J, Chhabra AK, Hart G (2000) An integrated SSR and RFLP linkage map of Sorghum bicolor (L.) Moench. Genome 43:988-1002 
Borad PK, Mittal VP (1983) Assessment of losses caused by pest complex to sorghum hybrid CSH 5. In: Krishnamurthy Rao BH, Murthy KSRK (eds) Crop losses due to insect pests. Entomological Society of India, Andhra Pradesh, India, pp 271-278

Bowers JE, Abbey C, Anderson S, Chang C, Draye X, Hoppe AH, Jessup R, Lemke C, Lennington J, Li Z, Lin Y-R, Liu S-C, Luo L, Marler BS, Ming R, Mitchell SE, Qiang D, Reischmann K, Schulze SR, Skinner DN, Wang Y-W, Kresovich S, Schertz KF, Paterson AH (2003) A highdensity genetic recombination map of sequence-tagged sites for Sorghum, as a framework for comparative, structural and evolutionary genomics of tropical grains and grasses. Genetics 165:367-386

Burd JD, Porter DR (2006) Biotypic diversity in greenbug (Hemiptera, Aphididae), characterizing new virulence and host associations. J Econ Entomol 99:959-965

Casas AM, Kononowicz AK, Zehr UB, Tomes DT, Axtell JD, Butler LG, Bressan RA, Hasegawa PM (1993) Transgenic sorghum plants via microprojectile bombardment. Proc Natl Acad Sci (USA) 90:11212-11216

Chittenden LM, Schertz KF, Lin YR, Wing RA, Paterson AH (1994) A detailed RFLP map of Sorghum bicolor $\times$ S. propinquum, suitable for high-density mapping, suggests ancestral duplication of Sorghum chromosomes or chromosomal segments. Theor Appl Genet 87:925-933

Dar WD (2009) Winning the gamble against the monsoons. http://www.hindu.com/2009/07/05/ stories/2009070555380900.htm

Deu M, Ratnadass MA, Hamada MA, Noyer JL, Diabate M, Chantereau J (2005) Quantitative trait loci for head-bug resistance in Sorghum. Afr J Biotechnol 4:247-250

Dhillon MK, Sharma HC, Naresh JS, Ram S, Pampapathy G (2006a) Influence of cytoplasmic male-sterility on different mechanisms of resistance in sorghum to shoot fly Atherigona soccata. J Econ Entomol 99(4):1452-1461

Dhillon MK, Sharma HC, Smith CM (2008) Implications of cytoplasmic male-sterility systems for development and deployment of pest resistant hybrids in cereals. CAB Rev Prospect Agric Vet Sci Nutrit Nat Res 3(068):1-16

Dhillon MK (2004) Effects of cytoplasmic male-sterility on expression of resistance to sorghum shoot fly, Atherigona soccata (Rondani) (Muscidae, Diptera). PhD thesis. Department of Entomology, Chaudhary Charan Singh Haryana Agricultural University, Hisar, Haryana, India, 382 pp

Dhillon MK, Sharma HC, Reddy BVS, Ram S, Naresh JS, Kai Z (2005) Relative susceptibility of different male-sterile cytoplasms in sorghum to shoot fly, Atherigona soccata. Euphytica 144:275-283

Dhillon MK, Sharma HC, Ram S, Naresh JS (2006b) Influence of cytoplasmic male-sterility on expression of physico-chemical traits associated with resistance to sorghum shoot fly, Atherigona soccata. SABRAO J Breed Genet 38:105-122

Dhillon MK, Sharma HC, Pampapathy G, Reddy BVS (2006c) Cytoplasmic male-sterility affects expression of resistance to shoot bug (Peregrinus maidis), sugarcane aphid (Melanaphis sacchari) and spotted stem borer (Chilo partellus). Intl Sorghum Millets Newslett 47:66-68

Dhillon MK, Sharma HC, Reddy BVS, Ram S, Naresh JS (2006d) Nature of gene action for resistance to sorghum shoot fly, Atherigona soccata. Crop Sci 46:1377-1383

Dhillon MK, Sharma HC, Folkertsma RT, Chandra S (2006e) Genetic divergence and molecular characterization of shoot fly-resistant and -susceptible parents and their hybrids. Euphytica 149:199-210

Eddleman BR, Chang CC, McCarl BA (1999) Economic benefits from grain sorghum variety improvement in the United States. In: Wiseman BR, Webster JA (eds) Economic, environmental, and social benefits of resistance in field Crops. Entomological Society of America, Lanham, MD, pp 17-44

Folkertsma RT, Sajjanar GM, Reddy BVS, Sharma HC, Hash CT (2003) Genetic mapping of QTL associated with sorghum shoot fly (Atherigona soccata) resistance in sorghum (Sorghum bicolor). In: Final abstracts guide, plant \& animal genome XI, 11-15 Jan 2003. San Diego, CA, USA, p 42. http://www.intl-pag.org/11/abstracts/P5d_P462_XI.html

Gao Z, Xie X, Ling Y, Muthukrishnan S, Liang GH (2005) Agrobacterium tumefaciens-mediated sorghum transformation using a mannose selection system. Plant Biotechnol J 3:591-599 
Girijashankar V, Sharma HC, Sharma KK, Sivarama PL, Royer M, Secundo BS, Lakshmi N, Seetharama N (2005) Development of transgenic sorghum for insect resistance against spotted stem borer, (Chilo partellus). Transgen Res (in press)

Harshavardhan D, Rani TS, Sharma HC, Arora R, Seetharama N (2002) Development and testing of $B t$ transgenic sorghum. In: International symposium on molecular approaches to improve crop productivity and quality, 22-24 May 2002, Tamil Nadu Agricultural University, Coimbatore, Tamil Nadu, India

Harvey TL, Hackerott HL (1969) Recognition of a greenbug biotype injurious to sorghum. J Econ Entomol 62:776-779

Heller W, Forkman G (1993) Biosynthesis of flavonoids. In: Harborne JB (ed) The flavonoids, advances in research since 1986. Chapman and Hall, London

Henzell RG, Brengman RL, Page FD (1980) Transference of sorghum midge resistance in to agronomically acceptable lines. In: Proc. 1st Australian Agronomy Conference. April 1980, Lawes, Queensland

Henzell RG, Jordan DR (2009) Grain sorghum breeding. In: Carena MJ (ed) Cereals. Springer Science, New York, pp 183-197

Howe A, Sato S, Dweikat I, Fromm M, Clemente T (2006) Rapid and reproducible Agrobacteriummediated transformation of sorghum. Plant Cell Rep 25:784-791

Huang Y (2004) Examining plant defense responses to greenbug attack in sorghum using DNA microarray technology. Intl Sorghum Millets Newslett 44:72-74

Huang Y (2006) Evaluating sorghum germplasm for resistance to greenbug (Schizaphis graminum) biotype I. Intl Sorghum Millets Newslett 47:72-74

Huang Y (2007) Phloem feeding regulates the plant defense pathways responding to both aphid infestation and pathogen infection. In: Zhi-hong Xu et al (eds) Biotechnology and sustainable agriculture 2006 and beyond. Springer, New York, pp 215-219

Huang Y (2008) Development of EST-SSR markers for sorghum and their transferability among cereal species. In: Proc. Intl. Plant \& Animal Genome Conference. 12-26 Jan 2008, San Diego, CA, pp 148

Huang Y (2011) Improvement of crop protection against insect pest using worldwide germplasm collection and genomics-based approaches. Plant Genet Resour Charact Utiliz 9:317-320

Hulbert SH, Richter TE, Axtell JD, Bennetzen JL (1990) Genetic mapping and characterization of sorghum and related crops by means of maize DNA probes. Proc Natl Acad Sci (USA) 87: 4251-4255

ICRISAT (1992) Annual report 1991. International Crop research Institute for Semi-arid Tropics. Patancheru, Andhra Pradesh, India

ICRISAT (International Crops Research Institute for the Semi-Arid Tropics) (1989) International workshop on sorghum stem borers, 17-20 Nov 1987, ICRISAT Center, Patancheru, Andhra Pradesh, India

Johnson JW, Rosenow DT, Teetes GL (1973) Resistance to the sorghum midge in converted exotic sorghum cultivars. Crop Sci 13:754-755

Johnson JW (1977) Status of breeding for midge resistance. 10th biennial grain sorghum research and utilization conference, 2-4 Mar 1977, Grain Sorghum Producers Association, Wichita, KS

Kim J-S, Klein PE, Klein RR, Price HJ, Mullet JE, Stelly DM (2005) Chromosome identification and nomenclature of Sorghum bicolor. Genetics 169:1169-1173

Kimber CT, Dahlberg JA, Kresovich S (2012) The gene pool of Sorghum bicolor and its improvement. In: Paterson AH (ed) Genomics of the saccharinae. Springer, New York, pp 23-41

Klein PE, Klein RR, Cartinhour SW, Ulanch PE, Dong J, Obert JA, Morishige DT, Schlueter SD, Childs KL, Ale M, Mullet JE (2000) A high-throughput AFLP-based method for constructing integrated genetic and physical maps. Progress toward a sorghum genome map. Genome Res 10:789-807

Kosambo-Ayoo LM, Bader M, Loerz H, Becker D (2011) Transgenic sorghum (Sorghum bicolor L. Moench) developed by transformation with chitinase and chitosanase genes from Trichoderma harzianum expresses tolerance to anthracnose. Afr J Biotechnol 10:3659-3670 
Kumar H (1993) Responses of Chilo partellus (Lepidoptera, Pyralidae) and Busseola fusca (Lepidoptera, Noctuidae) to hybrids of a resistant and a susceptible maize. J Econ Entomol 86:962-968

Kumar H, Mihm JA (1996) Resistance in maize hybrids and inbreds to first-generation southwestern corn borer, Diatraea grandiosella (Dyar) and sugarcane borer, Diatraea saccharalis Fabricius. Crop Prot 15:311-317

Kumari AP, Sharma HC, Reddy DDR (2000) Components of resistance to sorghum head bug, Calocoris angustatus. Crop Prot 19:385-392

Moran JL, Rooney WL (2003) Effect of cytoplasm on the agronomic performance of grain sorghum hybrids. Crop Sci 43:777-781

Mote UN (1984) Sorghum species resistant to shoot fly. Indian J Entomol 46:241-243

Painter H (1951) Insect resistance in host plants. Macmillan, New York, p 520

Park SJ, Huang Y, Ayoubi P (2006) Identification of expression profiles of sorghum genes in response to greenbug phloem-feeding using cDNA subtraction and microarray analysis. Planta 223:932-947

Pereira MG, Lee M, Bramel-Cox P, Woodman W, Doebley J, Whitkus J (1994) Construction of an RFLP map in sorghum and comparative mapping in maize. Genome 37:236-243

Peterson GC, Reddy BVS, Youm O, Teetes GL, Lambright L (1997). Breeding for resistance to foliar- and stem-feeding insects of sorghum and pearl millet. In: Proceedings of the International Conference on Genetic Improvement of Sorghum and Pearl Millet. INTSORMIL, Publ. 97-5, pp 281-302

Ramu P, Kassahun B, Senthilvel S, Ashok KC, Jayashree B, Folkertsma RT, Ananda Reddy L, Kuruvinashetti MS, Haussmann BIG, Hash CT (2009) Exploiting rice-sorghum synteny for targeted development of EST-SSRs to enrich the sorghum genetic linkage map. Theor Appl Genet 119:1193-1204

Reddy BVS, Stenhouse JW (1994) Improving post-rainy season sorghum, a case study for landrace hybrid approach. An invited paper presented at All India co-ordinated sorghum improvement project (A ICSIP) workshop held at Pantnagar, UP, 18-20 April

Rooney WL (2004) Sorghum improvement, integrating traditional and new technology to produce improved genotypes. Adv Agron 83:37-109

Ross WM, Kofoid KD (1979) Effect of non-milo cytoplasms on the agronomic performance of sorghum. Crop Sci 19:267-270

Sahrawat AK, Becker D, Lütticke S, Lörz H (2003) Genetic improvement of wheat via alien gene transfer, an assessment. Plant Sci 165:1147-1168

Satish K, Srinivas G, Madhusudhana R, Padmaja PG, Nagaraja Reddy R, Murali Mohan S, Seetharama N (2009) Identification of quantitative trait loci for resistance to shoot fly in sorghum [Sorghum bicolor (L.) Moench]. Theor Appl Genet 119:1425-1439

Seetharama N, Mythili PK, Rani TS, Harshavardhan D, Ranjani A, Sharma HC (2001) Tissue culture and alien gene transfer in sorghum. In: Singh RP, Jaiwal PK (eds) Improvement of food crops. Sci-Tech Publishing Company, Houstan, TX, pp 235-266

Schertz KF (1994) Male-sterility in sorghum: its characteristics and importance. In: Witcombe JR, Duncan RR (eds) Use of molecular markers in sorghum and pearl millet breeding for developing countries. In: Proceedings of the international conference on genetic improvement of an overseas development administration (ODA) plant sciences research conference, 29 March-1 April 1993, Norwich, UK, ODA, UK, pp 35-37

Sharma HC (1993) Host plant resistance to insects in sorghum and its role in integrated pest management. Crop Prot 12:11-34

Sharma HC (2001) Cytoplasmic male-sterility and source of pollen influence the expression of resistance to sorghum midge, Stenodiplosis sorghicola. Euphytica 122:391-395

Sharma HC, Abraham CV, Vidyasagar P, Stenhouse JW (1996) Gene action for resistance in sorghum to midge, Contarinia sorghicola. Crop Sci 36:259-265

Sharma HC, Dhillon MK, Naresh JS, Ram S, Pampapathy G, Reddy BVS (2004) Influence of cytoplasmic male-sterility on the expression of resistance to insects in sorghum. In: Fisher T, Turner N, Angus J, McIntyre L, Robertson M, Borrell A, Llyod D. (eds) Fourth international crop science congress, 25 September-October 1, 2004. Brisbane, Queensland, Australia 2007 
Sharma HC, Dhillon MK, Reddy BVS (2006) Expression of resistance to sorghum shoot fly in $\mathrm{F}_{1}$ hybrids involving shoot fly resistant and susceptible cytoplasmic male-sterile and restorer lines of sorghum. Plant Breed 125:473-477

Sharma HC, Franzmann BA (2001) Host plant preference and oviposition responses of the sorghum midge, Stenodiplosis sorghicola (Coquillett) (Dipt., Cecidomyiidae) towards wild relatives of sorghum. J Appl Entomol 125:109-114

Sharma HC, Nwanze KF (1997) Mechanisms of resistance to insects and their usefulness in sorghum improvement. Information bulletin no. 55. International Crop Research Institute for the Semi-Arid Tropics, Patancheru, Andhra Pradesh, India, $51 \mathrm{pp}$

Sharma HC, Reddy BVS, Dhillon MK, Venkateswaran K, Singh BU, Pampapathy G, Folkertsma RT, Hash CT, Sharma KK (2005) Host plant resistance to insects in sorghum, present status and need for future research. Intl Sorghum Millets Newslett 46:36-43

Sharma HC, Taneja SL, Kameswara Rao N, Prasada Rao KE (2003) Evaluation of sorghum germplasm for resistance to insect pests. Information bulletin no. 63. Patancheru, Andhra Pradesh, India, International Crops Research Institute for the Semi-Arid Tropics (CRISAT). 184 pp

Sharma HC, Taneja SL, Leuschner K, Nwanze KF (1992) Techniques to screen sorghums for resistance to insects. Information bulletin no. 32. International Crops Research Institute for the Semi-Arid Tropics (ICRISAT), Patancheru, Andhra Pradesh, India, 48 pp

Sharma HC, Vidyasagar P, Leuschner K (1988a) Field screening for resistance to sorghum midge (Diptera, Cecidomyiidae). J Econ Entomol 81:327-334

Sharma HC, Vidyasagar P, Leuschner K (1988b) No-choice cage technique to screen for resistance to sorghum midge (Diptera, Cecidomyiidae). J Econ Entomol 81:415-422

Sharma HC, Vidyasagar P, Abraham CV, Nwanze KF (1994) Effect of cytoplasmic male-sterility in sorghum on host plant interaction with sorghum midge, Contarinia sorghicola. Euphytica 74:35-39

Tao YZ, Hardy A, Drenth J, Henzell RG, Franzmann BA, Jordan DR, Butler DG, McIntyre CL (2003) Identifications of two different mechanisms for sorghum midge resistance through QTL mapping. Theor Appl Genet 107:116-122

Tatum LA (1971) The southern corn leaf blight epidemic. Science 171:1113-1116

Teetes GL, Pendleton BB (2000) Insect pests of sorghum. In: Smith CW, Frederiksen RA (eds) Sorghum, origin, history, technology, and production. Wiley, New York, pp 443-495

Tejinder K, Howe A, Sato S, Dweikat I, Clemente T (2012) Sorghum transformation: overview and utility. In: Paterson AH (ed) Genomics of the saccharinae. Springer, New York, pp 205-221

Tryon H (1895) The insect enemies of cereals belonging to the genus Cecidomyia. Trans Nat Hist Soc Queensland 1:80-83

Uknes S, Dincher S, Friedrich L, Negrotto D, Williams S, Thompson-Taylor H, Potter S, Ward E, Ryals J (1993) Regulation of pathogenesis-related Protein-1a gene expression in tobacco. Plant Cell 5:159-169

van den Berg J, van Rensburg GDJ, van der Westhiizen MC (1994) Host-plant resistance and chemical control of Chilo partellus (Swinhoe) and Busseola fusca (Fuller) in an integrated pest management system on grain sorghum. Crop Prot 13:308-310

Venkateswaran K (2003) Diversity analysis and identification of sources of resistance to downy mildew, shoot fly and stem borer in wild sorghums. Ph.D. thesis. Hyderabad, Andhra Pradesh, India, Department of Genetics, Osmania University

Venkateswaran K, Sharma HC, Manohar Rao D, Varaprasad KS, Bramel PJ (2009) Wild relatives of sorghum as sources of resistance to sorghum shoot fly, Atherigona soccata. Plant Breed $128: 137-142$

Ward ER, Uknes SJ, Williams SC, Dincher SS, Wiederhold DL, Aleander DC, Ahl-Goy P, Metraux JP, Ryals JA (1991) Coordinate gene activity in response to agents that induce systemic acquired resistance. Plant Cell 3:1085-1094

Wu J, Baldwin IT (2010) New insights into plant responses to the attack from insect herbivores. Ann Rev Genet 44:1-24 
Wu Y, Huang Y (2007) An SSR genetic map of Sorghum bicolor (L.) Moench and its comparison to a published genetic map. Genome 50:84-89

Wu Y, Huang Y (2008) Molecular mapping of QTLs for resistance to the greenbug Schizaphis graminum (Rondani) in Sorghum bicolor (Moench). Theor Appl Genet 117:117-124

Wu Y, Huang Y, Porter DR, Tauer CG, Hollaway L (2007) Identification of a major QTL conditioning resistance to greenbug biotype E in Sorghum PI 550610 using SSR markers. J Econ Entomol 100:1672-1678

Xu D, McElroy D, Thoraburg RW, Wu R (1993) Systemic induction of a potato pin 2 promoter by wounding methyl jasmonate and abscisic acid in transgenic rice plants. Plant Mol Biol 22:573-588

Yang W, de Oliveira AC, Godwin I, Schertz K, Bennetzen JL (1996) Comparison of DNA marker technologies in characterizing plant genome diversity, variability in Chinese sorghums. Crop Sci 36:1669-1676

Young WR, Teetes GL (1977) Sorghum entomology. Ann Rev Entomol 22:193-218

Zhuang X, Köllner TG, Zhao N, Li G, Jiang Y, Zhu L, Ma J, Degenhardt J, Chen F (2011) Dynamic evolution of herbivore-induced sesquiterpene biosynthesis in sorghum and related grass crops. Plant J 69:70-80

Zhao ZY, Cai T, Tagliani L, Miller M, Wang N, Pang H, Rudert M, Schroeder S, Hondred D, Seltzer J, Pierce D (2000) Agrobacterium-mediated sorghum transformation. Plant Mol Biol 44:789-798

Zhu-Salzman K, Salzman RA, Ahn J-E, Koiwa H (2004) Transcriptional regulation of sorghum defense determinants against a phloem-feeding aphid. Plant Physiol 134:420-431 